\title{
KEHARMONISAN SOSIAL PADA MASYARAKAT MULTIETNIS DAN POTENSINYA SEBAGAI SUMBER BELAJAR SOSIOLOGI (DI DESA CELUKANBAWANG, BULELENG, BALI)
}

\author{
Firawati Ariska, Prof. Dr Nengah Bawa Atmadja, M.A. Dr.I Ketut Margi, M.Si. \\ Program Studi Pendidikan Sosiologi \\ Jurusan Sejarah Sosiologidan Perpustakaan \\ Universitas Pendidikan Ganesha \\ Singaraja, Indonesia \\ e-mail: \{fira.ariska@gmail.com, \\ bawa.atmadja@undiksha.ac.idketut.margi@yahoo.co.id\}
}

\begin{abstract}
Abstrak
Penelitian ini bertujuan untuk mengetahui (1)Faktor-fakor pendukung terciptanya masyarakat harmonis di Desa Celukanbawang; (2) Strategi yang digunakan oleh masyarakat Desa Celukanbawang untuk menjadikan masyarakat yang harmonis; (3) Cara pemanfaatan keharmonisan sosial di Desa Celukanbawang yang memiliki potensi sebagai sumber belajar di SMA/MA. Konsep yang digunakan untuk menjawab rumusan masalah tersebut yakni Integrasi sosial, sosialisasi, dan teori AGIL Talcott Parsons. Pendekatan yang digunakan menggunakan pendekatan deskriptif kualitatif, dengan langkah: penentuan informan yang terdiri dari masyarakat Desa Celukanbawang yang bercorak multietnis serta tokoh agama Hindu, Islam yang merupakan warga Desa Celukanbawang. Pengumpulan data dilakukan melalui observasi, wawancara, dan studi dokumen.Analisa data dilakukan dengan langkah pengorganisasian data, reduksi, dan kesimpulan. Hasil penelitian menunjukkan 1) Terciptanya masyarakat multietnis yang hidup harmonis di Desa Celukanbawang 2) Pembentukan keharmonisan masyarakat multietnis yang harmonis dengan dibentuk melalui pendidikan didalam keluarga, sekolah serta masyarakat. 3) Aspek-aspek sosiologi yang dapat dijadikan sebagai sumber belajar sosiologi pada masyarakat celukanbawang dalam kehidupan masyarakat multietnis antara lain: integrasi sosial, sosialisasi, toleransi dan aktivitas sosial. Aspek ini dapat dikaitkan dengan materi pembelajaran Sosisologi SMA pada topik Perbedaan, Kesetaraan dan Harmoni Sosial.
\end{abstract}

Kata Kunci : Harmonisasi, Masyarakat Multietnis dan Sumber Belajar.

\begin{abstract}
This study aims to determine (1) Supporting factors for the creation of a harmonious community in Celukanbawang Village;(2) Strategies used by the people of Celukanbawang Village to make a harmonious community;(3) How to use social harmony in Celukanbawang Village which has potential as a source of learning in high school SMA / MA. The concept used to answer the problem formulation is social integration, socialization, and AGIL theory of Talcott Parsons. The approach used is using a qualitative descriptive approach, with steps: the determination of informants consisting of people from Celukanbawang Village who are multi-ethnic and Hindu religious figures, Islam, who are citizens of Celukanbawang Village. Data collection is done through observation, interviews, and document studies. Data analysis is done by organizing data steps, reduction, and conclusions. The results showed 1) The creation of a multi-ethnic society that lives in harmony in the Village of Celukanbawang 2) The formation of a harmonious multi-ethnic society that is harmonious by being formed through education within families,
\end{abstract}


schools and communities. 3) The aspects of sociology that can be used as a source of learning sociology in the community of Celukanbawang in the life of multi-ethnic society include: social integration, socialization, tolerance and social activities. This aspect can be related to high school sausageology learning materials on the topics of difference, equality and social harmony.

Keywords: Harmonization, Multiethnic Society and Learning Resources

\section{PENDAHULUAN}

Masyarakat multietnis adalah masyarakat yang terdiri dari bermacam suku, agama, ras dan budaya. Di negara indonesia keberagaman suku ras, agama dan budaya merupakan sebuah keniscayaan yang terjadi di dalam ruang lingkup masyarakat. Perbedaan pandangan antar suku budaya dan agama inilah yang sering kali memunculkan konflik di dalam masayarakat multietnik.

Berdasarkan berita yang termuat di media sosial bahwa, adanya isu konflik tentang agama belakangan ini semakin marak terjadi di Indonesia, seperti yang diketahui dalam lingkungan maupun kabar berita yang ada di media sosial. Banyak sekali isu konflik yang mengatas namakan agama sepertihalnya kasus bom bunuh diri di Surabaya yang mengatasnamakan satu agama untuk menyerang agama lain.Perbedaan dalam diskriminasi antar umat beragama di Indonesia terjadi karena dalam perbedaan pemahaman dalam nilainilai sosial yang diatur sebagaimana menjadi pertentangan umat beragama.yaitu kewajiban-kewajiban yang diwajibkan agamanya, ideal-ideal yang mengenai kepastian hak-hak umat beragama, pahampaham mengenai ajaran-ajaran dan pandangan-pandangan perbedaan doktrin. Adanya perbedaan mayoritas dan minoritas menjadi faktor timbulnya konflik antar umat beragama.Weber (dalam Retnowati,2014) juga mengungkapnkan fenomena konflik tidak sekedar dalam isu keagaamaan saja dan ketimpangan sumber daya saja, namun konflik terjadi luas dari hal-hal tersebut.

Oleh karena itu, penelitian tentang keharmonisan masyarakat multietnis di Desa Celukanbawanga masing masing etnis tersebut memiliki strategi dalam hubungan sosial dengan etnis yang berbeda guna menjalin hubungan yang harmonis. Keanekaragaman budaya, etnis

dan agama di Desa Celukanbawang sangat memungkinkan konflik antar agama atau adanya pertengkaran dengan kelompok tertentu dan individu. Namun kenyataanya tersebut tidaklah demikian, masyarat Desa Celukanbawang sampai saat ini hidup rukun dan harmonis. Hubungan sosial berjalan secara harmonis, interaksi antar individu dan kelompok selaras dalam suasan kebersamaan serta menjaga toleransi antar pemeluk agama.Kenyataan inilah yang menggugah kami untuk melakukan penelitian.Dengan adanya fenomena ini sangat menarik untuk diteliti didalam sosiologi dan sebagai bahan pembelajaran sosiologi di tingkat SMA/MA.

Desa Celukanbawang sudah menjadi tempat berbagai kultur dan ras dengan menjunjung tinggi rasa solidaritas dan menjaga toleransi yang erat kaitannya terhadap nilai-nilai fundamental, serta sebagai suatu keunikan didalam masyarakat yang bercorak multietnis. Dalam menciptakan sebuah keharmonisan dalam ranah multietnis sangat susah karena sangat majemuk. Masyarakat yang terdiri dari dua elemen dan hidup berdampingan secara harmonis seperti yang diketahui bahwa Desa Celukanbawangselalu di dominasi oleh masyarakat Jawa, Bugis, Madura dan lainnya yang menetap terbilang cukup lama, sehingga pendatang dan menetap di Desa Celukanbawang.Berkaitan dengan fenomena keharmonisan masyarakat multietnis di Desa Celukanbawang bahwa, tidak lepas dari adanya peran lembaga sosial sebagai ajang sosialisasi seperti keluarga, sekolah, dan masyarakat. 
Urgensi dari penelitian inidiharapkan dapat dijadikan sebagai pemahaman terhadap kompetensi dasar (KD) pada mata pelajaran sosiologi kelas XI, yaitu pada bab perbedaan, kesetaraan dan harmoni sosial.

Dengan demikian, pertanyaan yang dipecahkan dalam penelitian ini adalah: (1) mengapa masyarakat Desa Celukanbawang yang bercorak multietnis bisa meniptakan masyarakat yang harmonis?; (2) Bagaimana strategi yang digunakan oleh masyarakat Desa Celukanbawang untuk membangun masyarakat yang harmonis?; Bagaimana memanfaatkan keharmonisan sosial di Desa Celukanbawang sebagai sumber pembelajaran di MAN 1 Buleleng?. Sedangkan tujuan yang hendak dicapai yaitu: (1) Untuk mengidentifikasi dan mengetahui secara mendetail serta komprehensif tentang masyarakat Desa Celukanbawang yang bercorak multietnis bisa hidup berdampingan secara harmonis. (2) Untuk mengetahui strategi yang digunakan oleh masyarakat Desa Celukanbawang untuk menjadikan masyarakat yang damai. (3) untuk mengkaji dan menggali secara mendetail serta komprehensif tentang memanfaatkan keharmonisan di Desa Celukanbawang sebagai sumber pembelajaran di MAN 1 Buleleng.

Penelitian ini dapat dikaji dengan menggunakan beberapa teori yaitu: (1) Integrasi Sosial ialah membuat unsur-unsur tertentu menjadi satu kesatuan yang bulat dan utuh (Emiliana Sadilah 1997:24). Dalam kehidupan bersama manusia, integrasi selalu menjadi dambaan dan harapan setiap manusia, oleh karena itu, integrasi diusahakan untuk tumbuh dan dijaga kelangsungannya.Bentuk-bentuk Integrasi sosial terdiri dari Integrasi Keluarga, kekerabatan, integrasi asosiasi dan masyarakat. (2) Sosialisasi adalah hubungan dari berbagai unsur terdiri dari sikap, nilai, norma dan prilaku di masyarakat. Berikut agen dalam sosialisasi ialah keluarga, sekolah, agama, dan masyarakat (lingkungan tempat tinggal). (3) Teori AGIL Talcott Parsons yaitu, adaptasi,goal attaiment, integration dan latency. Menjelaskan bahwa agar tetap bertahan suatu sistem harus memiliki empat fungsi tersebut yang akan mempengaruhi dalam berprilaku dalam masyarakat dan beradaptasi dengan lingkungan sekitar dan sumber belajar bahwa, sumber belajar termasuk sistem dalam mendukung pembelajaran berbasis lingkungan.

\section{Metode Penelitian}

Metoda dalam peneliti menggunakan pendekatan kualitatif yang menggambarkan hubungan sosial masyarakat multietnis Desa Celukanbawang. Pendekatan kualitatif, laporan yang dihasilkan mencangkup masalah-masalah dalam lingkungan, dengan menggunakan jenis penelitian ini dapat membantu peneliti dalammemecahkan masalah yang sedang di teliti di masyarakat. Lokasi dalam penelitian ini di Desa Celukanbawang, Buleleng, Bali. Alasan mengambil lokasi dalam penelitian ini bahwa, dalam masyarakat Desa Celukanbawang terdapat masyarakat yang multietnis yang harmonis serta berguna dalam pembelajaran sosiologi di tingkat SMA/MA.

Selanjutnya, sumber data yang biasa digunakan dalam penelitian kualitatif ialah sebagai berikut: (1) Narasumber, dalam penelitian ini ialah masyarakat Desa Celukanbawang, masyarakat pendatang dan tokoh agama lainnya serta kepala kelurahan dan staff pegawai kelurahan Desa Celukanbawang. (2) aktifitas yang diambil dalam penelitian ini ialah aktifitas kegiatan sehari-hari dalam masyarakat Desa Celukanbawang. (3) Tempat atau lokasi penelitian ini beralamat di Desa Celukanbawang, Gerokgak, Bali. Dan (4) dalam penelitian ini peneliti mendapat data dengan mengambil gambar-gambar kegiatan di dalam masyarakat multietnis Desa Celukanbawang gambar yang diambil sesuai dengan rumusan masalah yang sudah dirancang didalam penelitian.Dalam penelitian ini, peneliti menggunakan tekhnik purposive samplingdan tekhnik snowball.Peneliti memilih dalam dua tekhnik penelitian tersebut agar data yang didapat dilapangan akurat dan jelas dengan rumusan masalah yang dirancang, peneliti mengambil data hanya di Desa Celukanbawang. Adapun informan yang diwawancarai yaitu: Kepala Desa 
Ceukanbawang, tokoh masing-masing agama serta masyarakat multietnis Desa Celukanbawang.

Metoda pengumpulan data yang digunakan yaitu, (1)obeservasi yang dilakukan adalah mengungkap data mengenai aspek data lokasi, waktu observasi, keadaan wilayah Desa Celukanbawang, kegiatan-kegiatan masyarakat Desa Celukanbawang etnik dan agama dan lainnya yang terkait dalam penelitian ini. Dalam penelitian ini melakukan observasi sebanyak enam kali; (2) informan yang diwawancarai yaitu, Bapak M. Ashari, Bapak Rahmansyah, Bapak kamarudin, serta warga masyarakat Desa Celukanbawang. (3) Dalam studi dokumen peneliti lebih banyak mengambil data berupa gambar, dokumentasi yang didapat yaitu profil kelurahan Desa Celukanbawang, foto aktivitas masyarakat Desa Celukanbawang serta kegiatankegiatan yang dilakukan dilingkungan Desa Celukanbawang. Hal tersebut dilakukan guna mencari data yang lebih jelas dan detail sehingga dalam penelitian ini jelas apa yang telah di bahas didalam penulisan artikel ini.

\section{Pembahasan}

Desa Celukanbawang berlokasi di Kecamatan Gerokgak, Buleleng, Bali.Desa ini memiliki rata-rata ketinggian 50 meter dari permukaan air laut.Luas wilayah Desa Celukanbawang $4,56 \mathrm{~km}$ jumlah penduduk 4.212 jiwa kepadatan 923 jiwa.

Celukanbawang adalah desa pesisir pantai yang berupa celuk sehingga sangat potensial dijadikan pelabuhan laut di kabupaten Buleleng.Di ujung pantai celukanbawang terdapat monumen perjuangan dari kapten wiroka.Nama Desa Celukanbawang merupakan nama yang diberikan oleh para penduduk Desa Celukanbawang yang awal mulanya bermukim di daerah yang mereka tempati sekarang ini.pemberian nama desa yang kemudian atas persetujuan masyarakat desa memberikan nama desa ini yaitu " Teluk Bawang" konon katanya dahulu desa ini menyerupai teluk dan seiring berkembngnya zaman dan banyaknya pendatang dari luar bali seperti Bugis, Jawa, Madura dan lainnya membuat tempat tinggal di desa ini dan mendiami selama beberapa tahun. Dalam sejarah desa celukanbawang berganti nama menjadi desa celukanbawang itu digantikan oleh kesepakatan bersama dan kepala desa yang baru oleh Bapak Ismail. Desa Celukanbawang memiliki masyarakat yang multikultural secara etnik dan agama, maka beragam suku dan agama tersebar diwilayah tersebut Keberadaan masyarakat multietnis yang terdapat di Desa Celukanbawang itu beragam dilihat dari data tabel mengenai etnik dan agama yang ada di Desa Celukanbawang guna memperjelas bahwa adanya masyarakat multietnis yang hidup berdampingan secara harmonis di Desa Celukanbawang berikut tabelnya.

Tabel 1.1

\begin{tabular}{|c|c|c|c|}
\hline $\begin{array}{l}N \\
\mathrm{O}\end{array}$ & ETNIK & LAKI-LAKI & $\begin{array}{c}\text { PEREMPUA } \\
\mathrm{N}\end{array}$ \\
\hline 1 & Bali & $\begin{array}{l}2105 \\
\text { orang }\end{array}$ & 1958 orang \\
\hline 2 & Bugis & 689 orang & 852 orang \\
\hline 3 & Jawa & 5 orang & 2 orang \\
\hline 4 & $\begin{array}{l}\text { Madur } \\
\text { a }\end{array}$ & 5 orang & 2 orang \\
\hline 5 & Sasak & 129 orang & 91 orang \\
\hline 6 & Sunda & 1 orang & 6 orang \\
\hline 7 & Aceh & 2 orang & - \\
\hline 8 & Batak & 2 orang & - \\
\hline 9 & Nias & 1 orang & - \\
\hline 10 & $\begin{array}{c}\text { Minan } \\
\mathrm{g}\end{array}$ & & 2 orang \\
\hline & Jumlah & 2953 & 2919 \\
\hline
\end{tabular}

Sumber. Profil Desa Celukanbawang,

Kecamatan Gerokgak, Buleleng, Bali. 2017 Dilihat pada tabel diatas yaitu 1.1 bahwa memang jelas etnik yang ada di Desa Celukanbawang sangatlah beragam, banyak pendatang dari luar yang menetap di Desa Celukanbawang.

Tabel 1.2 


\section{Sumber; Profil Desa Celukanbawang.}

Kecamatan Gerokgak, Buleleng, Bali. 2017 Berdasarkan pada tabel 1.2 diatas menjelaskan agama yang ada di Desa Celukanbawang sebagai data keras dalam penelitian masyarakat multietnis, bahwa di Desa Celukanbawang terdapat berbagai macam agama yaitu, Hindu, Islam, dan Kristen. Tempat ibadah di Desa Celukanbawang berupa masjid serta pura. Dalam kehidupan sehari-hari mereka saling menghormati sati sama lain walaupun berbeda keyakinan dan latar budaya. Justru perbedaan tersebut menjadi ciri pemersatu di antara mereka. Menjalin kerukunan antar umat beragama harus selalu terjalin dengan baik, apa lagi berada diwilayah yang multikultural seperti di Desa Celukanbawang. Oleh karena itu, setiap beragama diberi kebebasan dalam menjalankan ibadahnya.Peran pemerintah tokoh-tokoh agama dan lembaga adat sangat penting untuk selalu memberikan arahan dan nasehat agar selalu hidup rukun.

\section{Faktor- Faktor Pendukung Terciptanya Masyarakat Harmonis Di Desa Celukanbawang.}

Terciptanya suatu keharmonisan dalam masyarakat majemuk harus didasari dengan suatu unsur-unsur tertentu menjadikan satu kesatuan dalam menciptakan sebuah keharmonisan di Desa Celukanbawang, maka dari itu nilai-nilai fundamental didalamnya sangat berperan yaitu, nilai pancasila, agama serta kearifan lokal, yang dapat dijadikan dalam suatu pedoman didalamnya untuk menjaga suatu masyarakat yang bersifat majemuk hingga tidak akan terjadinya suatu konflik dan menjadikan desa tersebut secara harmonis.Masyarakat Desa Celukanbawang yang bercorak Multietnis dapat menciptakan keharmonisan dengan berpegang teguh pada nilai-nilai fundamental agama, pancasila, kelompok social serta komplemeter, sebagai berikut.

\section{a. Pancasila}

pancasilaadalah ideologi bangsa dan sebagai pedoman hidup dalam diri, meyakini dengan sila-sila pancasila agar

\begin{tabular}{|c|c|c|c|}
\hline $\begin{array}{c}\text { N } \\
\text { O }\end{array}$ & AGAMA & LAKI-LAKI & $\begin{array}{c}\text { PEREMPUA } \\
\text { N }\end{array}$ \\
\hline 1 & Islam & $\begin{array}{c}2265 \\
\text { orang }\end{array}$ & 2217 orang \\
\hline 2 & Hindu & 673 orang & 690 orang \\
\hline 3 & Kristen & 12 orang & 10 orang \\
\hline & Jumlah & $\begin{array}{c}2953 \\
\text { orang }\end{array}$ & 2919 orang \\
\hline
\end{tabular}

hidup rukun dan tidak adanya pembeda di antara masyarakat majemuk yang berada diwilayah Indonesi.Hal itu karena dalam Pancasila terdapat harmoni tentang kehidupan beragama dan berbudaya.Pancasila ini sebagai suatu pedoman dalam kehidupan.

\section{b. Agama}

Agama sebagai suatu kepercayaan seseorang dalam kehidupannya setiap agama adanya ajaran-ajaran yang terdiri dari nilai dan norma dalam berprilaku di masyarakat nilai-nilai fundamental yang mengarahkan manusia untuk meyakini keyakinannya masing-masing. Agama mengajarkan suatu nilai yang positif terhadap lingkungan serta agama sebagai pegangan hidup dalam diri manusia, lebih jelasnya didalam agama terdapat ajaranajaran kebaikan yang mengarah kepada keharmonisan dalam pembentukan sosial dalam masyarakat fungsinya sebagai suatu jalan menuju tolernsi antar umat beragama, serta tidak adanya suatu unsur yang menjatuhkan agama lain dalam hal apa pun yang mengarah kepada konflik didalamnya, maka dari itu setiap agama sudah memiliki caranya masing-masing agar menjadi pribadi yang baik didalam masyarakat dan berprilaku baik didalamnya sehingga membentuk satu kesatuan yang harmonis.

\section{c. Komplemeter}

Komplemeter ini diambil dari istilah ilmuImu ekonomi dan nilai komplemetr ini ialah nilai pelengkap, dalam mempererat suatu keharmonisan didalam masyarakat sudah dijelaskan diawal bahwa ada nilai fundamental agama, kearifan lokal serta dalam kehidupan komplemeter sebagai suatu pelengkap dan mempererat suatu keharmonisan.

\section{d. Kearifan lokal}

Istilah kearifan menurut bangsa Yunani Kuno disebut wisdom, yang berarti 
mengandung kecerdasan, etika, pola hidup yang selaras dengan alam atas dasar jiwa dalam keharmonisan (Supartha; 2007).Sedangkan, istilah lokal berarti di suatu tempat tentang pembuatan, produksi, tumbuhan, hidup, setempat, dsb.Adanya kecerdasan yang dimiliki masyarakat setempat tersebut kemudian dikembangkan untuk mengatur aspek kehidupan agar terwujud keharmonisan, kearifan lokal banyak mengandung macamnya. Diantaranya berupa norma, nilai, keunggulan pemikiran, sikap, tindakan, etika, estetika, teknologi, adat istiadat dan budaya serta keluhuran lainya.dapat dimanfaatkan oleh manusia untuk berbagai keperluan pola hidup yang lebih baik agar terwujudnya pola hidup yang rukun, harmonis da sejahtera.

Kearifan lokal ialah salah satu ciri khas yang ada didalam masyarakat tersebut, biasanya kearifan lokal didalam masyarakat ialah yang paling sering dilihat yaitu gotongroyong, saling menolong antar sesama.Dengan kearifan lokal bisa menjadikan masyarakat Desa Celukanbawang yangharmonis.

\section{Strategi digunakan oleh masyarakat Desa Celukanbawang untuk menjadikan masyarakat yang harmonis.}

Upaya dalam menjadikan masyarakat multietnis yang harmonis dapat dibentuk dalam pendidikan .Maka dari itu dalam pembentukan keharmonisan dalam suatu masyarakat multietnis dibentuk melalui pendidikan didalam keluarga, sekolah serta masyarakat.

\section{a. Keluarga}

Para sosiolog meyakini bahwa keluarga memiliki peran penting dalam menentukan kemajuan suatu bangsa, sehingga mereka berteori bahwa keluarga adalah unit yang penting sekali dalam masyarakat.Oleh karena itu para sosiolog yakin, segala macam keburukan masyarakat merupakan akibat lemahnya institusi keluarga.Bagi seorang anak keluarga merupakan tempat pertama dan utama bagi pertumbuhan dan perkembangnnya. Menurut resolusi Majelis Umum PBB, fungsi utama keluarga adalah sebagai wahana untuk mendidik, mengasuh dan mensosialisasikan anak, mengembangkan kemampuan seluruh anggotanya agar dapat menjalankan fungsinya di masyarakat dengan baik, serta, memberikan kepuasan dan lingkungan yang sehat guna tercapainya keluarga sejahtera".Maka dari itu, Pendidikan didalam keluarga ialah awal dari pengenalan seseorang, didalam keluarga diajarkan nilai-nilai kebaikan yang menjunjung hidup rukun keluarga tersebut, kemudian memiliki sikap peduli terhadap sesam dan menjaga keharmonisan didalamnya.Pendidikan didalam keluarga sangat penting dan yang paling utama dalam memperkenalkan anak terhadap nilai-nialai agama yang baik yang berkaitan terhadap lingkungan sekitar.

Peran orang tua dalam mewujudkan kepribadian anak antara lain:

a. Kedua orang tua harus mencintai dan menyayangi anak-anaknya

b. Kedua orang tua harus menjaga ketenangan lingkungan rumah dan menyiapkan ketenangan jiwa anakanak

c. Saling menghormati antara kedua orang tua dan anak-anak

d. Mewujudkan kepercayaan

e. Mengadakan kumpulan dan rapat keluarga (kedua oran tua dan anak)

Seperti yang diketahui dilapangan peneliti melakukan observasi wawancara kepada beberapa informan mengenai keluarganya.Tujuan dari wawancara ialah guna mendapatkan data yang sesuai dengan isu yang diangkat oleh peneliti.Berdasarkan hasil wawancara di lapangan tentang strategi yang dilakukan untukmenciptakan keharmonisan yaitu dilakukan di dalam pendidikan keluarga, sekolah dan pendidikan di masyarakat.

\section{Masyarakat}

Masyarakat merupakan salah satu pranata pendidikan yang diharapkan dapat bersinergi secara kokoh dengan pranata yang lainnya, yaitu lingkungan sekolah dan keluarga.Pendidikan masyarakat memberdayakan berbagai unsur (elemen) dan institusi yang sangat kaya dan beragam sehingga perannya sangat strategis.Masyarakat pun memiliki peran yang tidak kalah pentingnya dalam upaya 
pembentukan karakter anak bangsa. Dalam hal ini yang dimaksud dengan masyarakat disini adalah orang yang lebih tua yang tidak dekat, tidak dikenal,tidak memiliki ikatan famili " dengan anak tetapi saat itu ada di lingkungan sang anak atau melihat tingkah laku si anak. Orang-orang inilah yang dapat memberikan contoh, mengajak, atau melarang anak dalam melakukan suatau perbuatan.

Contoh-contoh perilaku yang dapat diterapkan oleh masyarakat:

a. Membiasakan gotong royong

b. Tegur sapa

c. Saling tolong menolog

d. Dan menjaga toleransi antar umat beragama.

Dalam pendidikan Multikultural terhadap masyarakat bertujuan untuk memberikan pandangan yang luas tentang manfaat suatu perbedaan yang ada di dalam kelompok masyarakat.Terkait dengan pendidikan dalam masyarakat untuk menciptakan suatu keharmonisan di dalam masyarakat multietni Desa Celukanbawang.

\section{b. Sekolah}

Pembentukan suatu keharmonisan peran sekolah juga termasuk pembentukan anak, dimana dalam sekolah kelompok bermain akan mempengaruhi pergaulan anak serta disekolah adalah agen kedua dalam sosialisasi yang membentuk suatu tatanan anak yang memiliki sikap baik terhadap orang lain dan dapat menghargai antar sesame manusia yang berbeda etnis maupun agama.

\section{Aspek- Aspek Keharmonisan Sosial di Desa Celukanbawang yang Memiliki Potensi Sebagai Sumber Belajar Sosiologi di SMA/MA.}

Sumber belajar yang digunakan masih terpaku pada guru, buku paket, dan lainnya. Seharusnya di dalam proses pembelajaran seorang guru dapat mencari dan menggunakan sumber belajar dari sekitar lingkungan yang secara tepat akan memberikan kemudahan dalam pencapaian kompetensi. Dalam hal ini mengingat bahwa sumber belajar mempunyai potensi yang cukup besar untuk mengembangkan dan memperjelas materi pembelajaran yang akan disampaikan kepada peserta didik. Implementasi dalam sumber belajar agar proses pembelajaran efektif yang dijelaskan dalam kurikulum 2013.

Adanya suatu pembelajaran bertujuan dalam menyampaikan suatu materi yang terdapat dalam suatu mata pelajaran, salah satu mata pelajaran yang menggunakan sumber belajar guna menopang dalam menyampaikan suatu materi pembelajaran kepada peserta didik dalam mata pelajaran sosiologi, kajian tentang masyarakat multietnis cocok untuk dijadikan sebagai suplemen materi pelajaran sosiologi kelas XI Semester 2 pada Bab keharmonisan sosial masyarakat multietnis, sesuai dengan Kompetensi Dasar (KD) 3.1 yakni Memahami arti penting prinsip kesetaraan untuk menyikapi perbedaan sosial demi terwujudnya kehidupan sosial yang damai dan demokratis.Mata pelajaran sosiologi merupakan pembelajaran dalam masyarakat, mengenai fenomena yang terjadi didalam masyarakat, maka dalam pembelajaran ini dapat digunakan dalam penyampaian materi bisa berupa kegiatan melalui observasi dan wawancara di lingkungan masyarakat. Adanya sumber belajar itu dapat berfungsi sebagai berikut: Pertama, meningkatkan produktifitas pendidikan dengan membantu guru dalam mengalokasikan waktu sehingga dapat tercapainya tujuan pembelajaran. Kedua, memberikan kesempatan kepada peserta didik untuk berfikir kritis terhadap fenomena dalam masyarakat dan dapat mengembangkan kemampuannya.Ketiga, memberikan dasar-dasar dan memberikan pengajaran secara sistematis.Keempat, meningkatkan dalam pembelajaran agar mudah dipahami oleh peserta didik dengan memahami dilingkungan sekitarnya.

Adapun aspek-aspek sosiologi yang dapat dijadikan sebagai sumber belajar dalam penelitian ini tentang masyarakat multietnis bab sesuai dengan Kompetensi Dasar (KD) ialah sebagai berikut:

Kompetensi Dasar 3.3 memahami penerapan prinsip-prinsip kesetaraandalam menyikapi keberagaman untuk menciptakan kehidupan harmonis dalam masyarakat.4.2 merumuskan strategi dalam menciptakan kehidupan yang harmonis 
dalam masyarakat berdsar prinsip-prinsip kesetaraan dalam materi pokok perbedaan, kesetaraan dan harmonisosial.Aspek-aspek yang dikemukakan oleh Bloom yakni aspek afektif, kognitif dan psikomotorik yang sesuai dengan kompetensi inti $(\mathrm{KI})$.

\section{Aspek Afektif}

Aspek Afektif adalah aspek mencakup tentang sikap, minat dan emosi peserta didik. Dalam kurikulum 2013 dijelaskan tentang aspek Afektif yang terdapat dalam kompetensi iti (KI) I dan II yang berbunyi, KI I :Menghayati dan mengamalkan ajaran agama yang dianutnya dan $\mathrm{KI}$ II: Mnunjukkan prilaku jujur, disiplin, tanggung jawab, peduli (Gotong royong , toleransi, kerjasama, damai). Dalam penjabaran KI I dan KI II dijelaskan bahwa dalam penelitian Keharmonisan sosial masyarakat multietnis ini dapat dijadikan sebagai materi pelajaran sosiologi kelas XI dimana dalam materi pokok perbedaan, kesetaraan dan harmonisosial.Didalam kehidupan bermasyarakat sangatlah beragam dan multietnis dimana didalamnya terdapat kepercayaan bahwa setiap agama menganjurkan pemeluknya untuk hidup rukun bersama dan menjaga toleransi antar sesama umat beragama sehingga terciptanya sebuah keharmonisan didalam masyarakat yang telah terbentuk di masyarakat Desa Celukanbawang, Gerokgak, Bali. Dengan penelitian ini dapat dijadikan sebagai sumber belajar sosiologi dimana peserta didik dapat memahaminya dilapangan karena jika mengambil contoh di lapangan peserta didik akan lebih berfikir kritis dan memahami langsung serta akan berdampak langsung didalam kehidupannya dalam kehidupan harmonis.

\section{Aspek Kognitif}

Peseta didik harus memahami dalam Bloom yaitu Aspek Kognitif, aspek kognitif ialah aspek yang berkaitan dengan tentang intelektual pada peserta didik.Aspek kognitif jika dikaitkan dengan kurikulum 2013 yang sesuai dengan Kompetensi Inti (KI) III, yaitu memahami, menerapkan dan menganalisis faktual, konseptual, prosedural, teknologi, seni dan budaya. Penelitian tentang Keharmonisan Sosial Mayarakat Multietnis dalam KI III telah berkaitan dengan bagaimana peserta didik dapat mengetahui kehidupan masyarakat yang multietnis bercorak harmonis dengan menjunjung tinggi dari nilai-nilai fundamental yang dapat dijadikan sebagai pedoman didalam masyarakat multietnis sehingga pendatang yang menetap di desa celukanbawang dapat memahami arti dari nilai-nilai fundamental yang berlaku agar selalu menjaga kerukunan umat beragama diharapkan mampu dijadikan sebagai dasar pembentukan keharmonisan sehingga siswa menyadari hidup rukun dalam multietnis. Kemudian dari contoh-contoh yang real didalamnya bisa dijadikan sebagai sumber belajar dan pemhaman pada masyarakat multietnis harmonis sehingga pengetahuan yang didapat melalui lapangan siswa dapat berfikir kritis dan dapat berperan didalamnya.

\section{Aspek Psikomotor}

Aspek Psikomotor atau yang disebut sebagai aspek keterampilan/ kemampuan bertindak. Aspek ini ika dikaitkan dengan kurikulum 2013 yang sesuai dengan kompeetensi ini (KI) IV, yang berbunyi :mengolah, menalar, dan menyaji dalam ranah konkret dan abstrak terkait dengan pengembangan dari yang telah dipelajari disekolah yang bertindak secara efektif, kreatif serta mampu menggunakan metoda kaidah keilmuan. Dalam aspek ini peserta didik diharapkan mampu mengaplikasikan pemahaman tentang masyarakat multietnis harmonis dalam kehidupan sehari-hari menggunakan konsep sosiologi yang telah didapat sehingga dalam kehidupan seharihari peserta didik sudah memahaminya dalam masyarakat.

\section{Simpulan}

Kesimpulan ini merupakan ringkasan dari jawaban atas rumusan masalah atau hasil dari temuan penelitian masyarakat desa celukanbawang yang bercorak multietnis bisa menciptakan mayarakat harmonis. Pertama Menciptakan sebuah keharmonisan sosial dalam ranah multietnis nilai-nilai fundamental didalamnya sangat berperan yaitu, nilai pancasila, agama serta kearifan lokal. Penanaman nilai ini dilakukan agar terbentknya atau terciptanya suatu 
keharmonisan dan saling menghargai perbedaan. Warga pendatang terjadilah pertemuan dari berbagai penduduk, sehingga mereka mulai saling menghargai satu sama lain. Secara sosiologis masyarakat telah selesai dalam fase-fase integrasi, yakni asimilasi, akomodasi dan kerjasama.Kedua Strategi yang digunakan oleh masyarakat desa celukanbawang untuk menjadikan masyarakat yang harmonis upaya dalam menjadikan masyarakat multietnis yang harmonis dapat dibentuk dalam pendidikan yang merupakan medium bagi proses transmisi pengetahuan, system nilai serta keterampilan yang bertujuan melahirkan manusia bijak, berakhlak mulia dan berkeadaban. Outpit dari suatu proses pendidikan yang baik, diharapkan dapat melahirkan warga Negara yang baik (Good citizen) dimana warga Negara yang baik itu akan meningkatkan keadaan lingkungan masyarakat akan membaik dan membangun masyarakat yang harmonis. Maka dari itu dalam pembentukan keharmonisan dalam suatu masyarakat multietnis dibentuk melalui pendidikan didalam keluarga, sekolah serta masyarakat.Ketiga Keharmonisan masyarakat multietnis desa celukanbawang yang memiliki potensi sebagai sumber belajar sosiologi di sma/ma. Secara

sosiologi dalam pembentukan suatu keharmonisan masyarakat multietnis di Desa Celukanbawang harus dilestarikan bagi generasi muda lewat pendidikan sekolah pelajaran Sosiologi, peserta didik dapat memiliki pengetahuan mengenai bagaimana melakukan pemecahan masalah untuk mengatasi permasalahan sosial, konflik dan kekerasan di masyarakat serta peserta didik dapat melakukan penelitian sederhana di lapangan berkaitan dengan permasalahan sosial dan konflik yang terjadi di masyarakat sekitar.Sesuai dengan penjelasan mengenai aspek-aspek di atas, penelitian ini mempunyai potensi sebagai sumber belajar sosiologi di SMA/MA Kela XI dalam Bab kesetaraan dan keharmonisan sosial. Potensi yang dimaksud dipaparkan dalam bentuk Rancangan Pelaksanaan Pembelajaran (RPP).

\section{Saran}

Berdasarkan hasil penelitian yang dilakukan ada beberapa hal yang ingin disampaikan penulis sebagai sumbangan saran terkait dengan penelitian yang dilakukan, yaitu:

1.Bagi pelajar, dengan adanya fenomena dalam ranah keharmonisan masyarakat multietnis dapat dijadikan sebagai cerminan akan pentingnya sebuah keharmonisan dan kerukunan, terutama di sekolah, sekaligus dapat di praktekan sehingga dapat dijadikan contoh oleh pelajar untuk selalu melakukan hal-hal yang positif, menjunjung tinggi sikap toleransi antar umat beragama. Disamping itu semoga dapat bermanfaat sebagai sumber pembelajaran Sosiologi di tingkat SMA/MA.

2.Untuk peneliti yang lainnya agar meneliti lebih lanjut dalam konteks keharmonisan agar mendapatkan pengetahuan yang luas didalam masyarakat yang bercorak multietnis dalam konteks harmonis.

3. Bagi penulis, menyadari bahwa tulisan ini masih jauh dari kata sempurna sehingga kritik maupun saran dari pembaca sangat diharapkan demi kesempurnaan penulisan skripsi di kemudian hari, dan bagi penulis lain semoga penelitian ini dapat menambah wawasan ketika penulis lain melakukan penelitian sejenis dan nantinya mampu untuk melengkapi tu;isan ini.

4.Kepala Desa Celukanbawang teruslah mengabdi didalam masyarakat dan selalu membentuk keharmonisan di dalamnya dengan menjaga interaksi antar sesama seperti bentuk-bentuk kegiatan masyarakat yaitu kegiatan gotong royong dan lainnya dalam membentuk suatu keharmonisan.

\section{Daftar Pustaka}

Hamdi, Ahmad Zainul dan Mukhtafi. 2017. Wacana dan Praktil Pluralisme keagamaan di Indonesia. Jakarta: Daulat Jakarta Press. 
Nasution. 2011. Sosiologi Pendidikan. Jakarta: PT Bumi Aksara.

Sanjaya, Wina. 2008. Perencanaan dan Desain Sistem Pembelajaran. Jakarta: Kencana Prenada Media Group.

Sugiyono. 2010. Metode Penelitian Pendidikan. Bandung: Alfabeta

Rirzer, George. 2014. Teori Sosiologi Moderen Edisi Ketuju. Jakarta: Prenada Media Group

Adipurnomo, Haryono. 2006. Sumber dan Media Pembelajaran. Departemen Pendidikan Nasional

Hendropuspito, 1983.Sosiologi Agama. Yogyakarta: Yayasan Kanisuis (anggota IKAPI)

Sukardi.2003. Metodologi Penelitian Pendidikan Kompetensi dan Praktiknya.Jakarta: PT Bumi Aksara.

Raga, Gede.Dkk. 2003.Integrasi Sosial Antar Umat Hindu dan Islam di Bali (Study Kasus di Desa Candikuning, Tabanan, Bali).IKIP Singaraja

Saputra, Herman, dkk. 2013. Integrasi Sosial Masyarakat Multietnik Di Desa Gerokgak, Kecamatan Gerokgak, Kabupaten Buleleng. Jurnal Pendidikan, 5(12): 12-15.

Ayu Armini. 2013. Toleransi Mayarakat Multi Etnis Dan Multiagama Dalam Organisasi Subak Di Bali. Jurnal Pendidikan

Abdul Rahman Sinaga. 2016. Pola Komunikasi Masyarakat Kampung Bali (Study Deskriptifetnografi Pola Komunikasi Masyarakat Suku Bali Dalam Berinteraksi Dengan Masyarakat Yang Multietnis Di Desa Cipta Dharma). 